\title{
The Reflections of Differentiated Science Education For Gifted Students on Prospective Classroom Teachers
}

\author{
Nese Kutlu Abu \\ Amasya University, Faculty of Education, Department of Elementary and Early \\ Childhood Education, Amasya 3800, Turkey \\ ORCID : 0002-4251-3627
}

\begin{tabular}{|c|c|}
\hline Article history & This study was designed to delve into the impact of differentiated \\
\hline $\begin{array}{l}\text { Received: } \\
25.05 .2020\end{array}$ & $\begin{array}{l}\text { science education for gifted students on prospective classroom } \\
\text { teachers in terms of some variables. A concurrent embedded }\end{array}$ \\
\hline $\begin{array}{l}\text { Received in revised form: } \\
18.10 .2020\end{array}$ & $\begin{array}{l}\text { research design from mixed research methodologies was employed } \\
\text { in this study. The participants were } 69 \text { sophomore students } \\
\text { studying in the Department of Primary Education in the Faculty of }\end{array}$ \\
\hline $\begin{array}{l}\text { Accepted: } \\
29.10 .2020\end{array}$ & $\begin{array}{l}\text { Education in Amasya University during } 2018-2019 \text { academic year. } \\
\text { The data collection instruments were the Science Teaching }\end{array}$ \\
\hline Key words: & Efficacy Belief Scale, the Academic Self-Efficacy Scale, the \\
\hline $\begin{array}{l}\text { Differentiated science } \\
\text { teaching, } \\
\text { Prospective classroom } \\
\text { teachers, } \\
\text { Science teaching efficacy } \\
\text { belief. }\end{array}$ & $\begin{array}{l}\text { Activities Performing Scale, and a structured interview form. For } \\
\text { the qualitative data, a deductive approach was employed, and } \\
\text { themes and codes were used to show the findings. Based on the } \\
\text { results, there is evidence to suggest that differentiated science } \\
\text { education applications develop prospective teachers' science } \\
\text { teaching efficacy beliefs, their competences for learning science, } \\
\text { their academic self-efficacies, and their outdoor science activity } \\
\text { performing beliefs. The findings also show most of the participants } \\
\text { hold the belief that their educational background contributes to } \\
\text { their professional and personal developments as well as science } \\
\text { teaching skills, and helps them gain awareness of such concepts as } \\
\text { giftedness, outdoor learning, and differentiated teaching. Several } \\
\text { recommendations for making differentiated education prevalent } \\
\text { for prospective teachers are provided. }\end{array}$ \\
\hline
\end{tabular}

\section{Introduction}

Gifted and talented students studying at primary schools have been neglected in regular classrooms, and interests, talents and potentials of these children cannot be fully recognized (Archambault, Brown, Hallmark, Zhang and Emmons, 1993; Bernal, 2003; Launder, 2011; Prior; 2011; Smith, 2006; Stepanek, 1999). Gifted and talented students are individuals who need curriculums with comprehensive concepts, themes and problems; depend on scientific inquiry, active learning, and problem solving; need small groups or independent learning groups as well as curriculums with challenging, comprehensive, complex, and intangible patterns with integrated curricular activities 
(Renzulli, 2012; Tomlinson, 2004; VanTassel-Baska and Wood, 2010). Previous research has revealed that during the regular classroom with traditional instruction, gifted and talented students do not have any incentives motivating them to challenge themselves. Further, revising the subjects they have already mastered does not catch their interest, and so they begin to feel bored in the classroom and to suffer from lack of motivation (Bernal, 2003; Kaplan, 2012; Renzulli and Reis, 2009; Tomlinson, 2000, 2004). In a study by Reis et al. (1993), it has been revealed that gifted students cannot benefit from differentiated instructions during most of the learning activities in regular classrooms. In this sense, the full potentials of gifted and talented students who cannot take the advantage of differentiated education are not fully developed. Their talents cannot be developed from the very early years of life, and their self-realizations are hindered (Olszewski-Kubilius and Thomson, 2015; Renzulli, 2005).

Classroom teachers hold significant missions and responsibilities in developing the interests and talents of the gifted and talented students from the early ages in regular classrooms (Hertberg-Davis, 2009; Heacox, 2002; Tomlinson, 2001). Classroom teachers are those expected to teach such subjects such as literacy, maths, science, social sciences, citizenship, art, and sports in their educational organizations. In addition to having pedagogical and content knowledge in different fields, they must have the necessary knowledge, skills and competences to design and to implement diverse educational environments that satisfy all students considering individual differences (Tomlinson, 2003; Tomlinson, Brighton, Hertberg, Callahan, Moon et. al., 2003). Such competences as grasping the cognitive and affective characteristics of gifted students, and planning, implementing and assessing the methods, approaches, strategies and techniques that promote the talents of these students bespeak the competencies of classroom teachers (Akar, 2020). A qualified education is of great importance not only for students with average or below intelligence, but also for gifted and talented students based on their interests, talents, and needs so that they can flourish themselves in several disciplines (Heacox, 2002). Research indicates that classroom teachers in regular classrooms mostly neglect gifted/talented students and believe that these students do not need special or differentiated education (Kutlu Abu, Akkanat and Gokdere, 2017; Caldwell, 2012). These teachers have negative attitudes towards the education of gifted students, and have not fully developed the necessary knowledge, skills or competencies in differentiated educational activities (Westberg et al., 1993; Westberg and Daoust, 2004).

Past research has revealed that classroom teachers consider themselves incompetent during pull-out classes for gifted students and find teaching materials insufficient to use in gifted education (Caldwell, 2012). These teachers, on the other hand, are willing to attend in-service trainings for achieving differentiated teaching design skill, and need several curriculums for gifted education (Akar, 2020). Although there have been several in-service training programmes such as Detecting and Supporting Gifted Children, Teacher Education for Gifted, and Preparing Materials for Gifted for classroom teachers in literature (Powers, 2008; Rowley, 2002; Tomlinson, 2004), it is seen that there are few programs designed for prospective classroom teachers which include specific content, like science or maths. This may be due to the fact that there are not many field experts in gifted education, and there are few graduate programmes. Most of the gifted students are taught in regular classrooms. In order for these children to be supported in regular classrooms in primary schools, there needs more research on prospective teachers.

Previous research has found that gifted students are not adequately supported in science 
courses; they feel disappointed during science courses; basal texts are frequently used in these courses; these tests do not provide them with challenging and motivating problem solving activities; and gifted students are not allowed to conduct in-depth investigations. Further, some more studies have provided evidence that gifted students prefer practical activities rather than those based on memorizing; they would rather face real-life situations in which they can solve problems and can conduct investigations. What is more, the Science course books do not enable them to involve detailed inquiries and problem solving and have been prepared according to the levels of average students (Johnson et al., 2005; Robinson, Shore and Enersen, 2007). Brilliant students cannot have the chance to study with suitable content at challenging levels (Robinson, Shore and Enersen, 2006). Unless teachers design the curriculum according to levels of gifted students, their attitudes towards science course do not develop, and they cannot show their full potentials (Harshbarger, 2015; Rogers, 2002). Teachers are supposed to be aware of the approaches in which all students, gifted or the ones who cannot learn without assistance, and are expected to develop their content knowledge and pedagogical skills in this direction (Callahan, Moon, Oh et. al, 2015; Harshbarger, 2015; Westburg et. al., 1993). Taber (2011) suggested that it is necessary to delve into the methods by which the thinking skills of gifted students in Science can be developed determining developmental, curriculum, and metacognitive frameworks in gifted education, and highlighted the importance of teacher education.

It is of crucial importance to support successful teachers in regular classrooms who conduct such activities as early-birds corner, additional activities, elective activities and independent research (Akar, 2020), who employ differentiated strategies based on the students' interests, learning styles, intelligence types, and socio-emotional developments (Renzulli, 2005, 2012; Tomlinson, 2003, 2001), and who successfully implement several differentiated models (Taber, 2011; Tomlinson, 2001; Renzulli and Reis, 2009; Kaplan, 2012; VanTassel-Baska and Brown, 2009). In this way, gifted students in regular classrooms can be provided with an effective science teaching based on inquiry which can engage them with high-level thinking skills and can provide depth and complexity for their instruction.

Previous research has unearthed that teachers' or prospective teachers' self-efficacies towards Science teaching (Kinskey, 2018; Knaggs \& Sondergeld, 2015; Menon \& Sadler, 2016; Trauth-Nare, 2015; Avery \& Meyer, 2012) and Science teaching competencies (Chang et. al., 2011) were found as moderate/low level. It has also been found that their knowledge on differentiated applications such as outdoor learning activities was limited (Marentin and Guisasola, 2009; Tsai, 2006), and their academic self-efficacies were found as moderate level (Schunk, 1985; Sokmen, 2018). An examination of the literature shows no research on the effect of the Science teaching module as is the case with this study on prospective teachers in terms of some variables. At this precise point, it would yield fruitful results in the literature to conduct studies which recruit prospective classroom teachers, based on investigation, questioning and practice in order to develop education models that include alternative evaluation and assessment tools in primary schools to support gifted students in science. In this study, a science teaching module based on the practice was developed to allow gifted students to achieve personal and social developments. Then, the reflections of this module on prospective teachers have been examined in terms of several variables through a mixed-research methodology. 


\subsection{Purpose of the research and hypotheses}

This study was to design a differentiated science teaching module for gifted students, and to examine its impact on prospective classroom teachers in terms of science teaching efficacy beliefs, competences for learning science, outdoor science activities performing beliefs, and academic self-efficacies. This study is significant in that it helps prospective teachers become aware of giftedness and assists them to gain knowledge, skills and competencies in designing learning environments that develop $21^{\text {st }}$ century skills of gifted students in science education. Designed as a mixed-research methodology, this study is expected to contribute to the related literature, providing evidence for curriculum designers who develop curriculums for prospective teachers in terms of science teaching.

The main research question in this study is as follows: What effect does the differentiated science teaching training for science teaching to gifted students have on prospective classroom teachers? The independent variable in this study is the differentiated science teaching module, while (i) science teaching efficacy beliefs, (ii) competences for learning science, (iii) outdoor science activities performing beliefs and (iv) academic selfefficacies are the dependent variables. The sub-research problems framing the study are as follows:

(1) Does the differentiated science teaching module impact prospective teachers' science teaching self-efficacy perceptions?

(2) Does the differentiated science teaching module impact prospective teachers' competence scale for learning science?

(3) Does the differentiated science teaching module impact prospective teachers' outdoor science activities performing perceptions?

(4) Does the differentiated science teaching module impact prospective teachers' academic self-efficacy perceptions?

(5) What do prospective teachers in the experimental group think about DEST applications?

(6) How is the conceptual awareness of the participants in the control group towards the basic concepts in DSET?

The research hypotheses and their sub-problems are presented in Table 1.

Table 1 Research sub-problems and hypotheses

\begin{tabular}{|c|c|}
\hline \\
\hline \multicolumn{2}{|r|}{$\begin{array}{l}\text { Sub-research problem 3. Does DSET impact } \\
\text { prospective teachers' outdoor science activities } \\
\text { performing perceptions? } \\
\text { Hypothesis 7. There is no statistically significant } \\
\text { difference between outdoor science activities } \\
\text { performing perceptions' pre-test scores of prospective } \\
\text { teachers in the control and experimental groups. }\end{array}$} \\
\hline $\begin{array}{l}\text { Hypothesis } 2 \text {. There is statistically significant difference } \\
\text { between science teaching self-efficacy perceptions' } \\
\text { post-test scores of prospective teachers in the control and } \\
\text { experimental groups. }\end{array}$ & $\begin{array}{l}\text { Hypothesis } 8 . \text { There is statistically significant } \\
\text { difference between outdoor science activities } \\
\text { performing perceptions' post-test scores of prospective } \\
\text { teachers in the control and experimental groups. }\end{array}$ \\
\hline $\begin{array}{l}\text { Hypothesis 3. There is statistically significant difference } \\
\text { between science teaching self-efficacy perceptions' pre- } \\
\text { and post-test scores of prospective teachers in the control } \\
\text { and experimental groups. }\end{array}$ & $\begin{array}{l}\text { Hypothesis 9. There is statistically significant } \\
\text { difference between outdoor science activities } \\
\text { performing perceptions' pre-and post-test scores of } \\
\text { prospective teachers in the control and experimental } \\
\text { groups. }\end{array}$ \\
\hline
\end{tabular}


Sub-research problem 2. Does DSET impact prospective teachers' competence scale for learning science?

Hypothesis 4. There is no statistically significant difference between competence scale for learning science pre-test scores of prospective teachers in the control and experimental groups.

Hypothesis 5. There is statistically significant difference between competence scale for learning science post-test scores of prospective teachers in the control and experimental groups.

Hypothesis 6. There is statistically significant difference between competence scale for learning science pre-and post-test scores of prospective teachers in the control and experimental groups.

$\begin{array}{llrr}\begin{array}{l}\text { Sub-research } \\ \text { prospective } \\ \text { perceptions? }\end{array} & \begin{array}{c}\text { problem } \\ \text { teachers' }\end{array} & \begin{array}{l}\text { 4. Does } \\ \text { academic }\end{array} & \text { DSET impact } \\ \text { self-efficacy }\end{array}$

Hypothesis 10. There is no statistically significant difference between academic self-efficacy perceptions' pre-test scores of prospective teachers in the control and experimental groups.

Hypothesis 11. There is statistically significant difference between academic self-efficacy perceptions' post-test scores of prospective teachers in the control and experimental groups.

Hypothesis 12. There is statistically significant difference between academic self-efficacy perceptions' pre-and post-test scores of prospective teachers in the control and experimental groups.

\section{Theoretical Background}

\subsection{Science Teaching Efficacy Belief}

The basic idea of the Social Cognitive Theory (SCT) is based on person, behavior and environment, and there is a reciprocal interaction among them (Bandura, 1977). According to this theory, self-efficacy is defined as one's belief in their ability to realize future tasks or become successful in specific situations or in achieving a task. In this theory, self-efficacy is not a stable character trait but a belief that develops and is learned (Dellinger, Bobbett, Olivier and Ellett, 2008). Bandura suggests that four basic factors impact the person: mastery experience, vicarious experience, verbal persuasion, and emotional arousal (Bandura and Adams, 1977). Those with high level self-efficacy beliefs have better intrinsic target orientations and analytical thinking skills. Negative beliefs towards one's talents have adverse effects on their performances, damaging their analytical thinking (Bong, Cho, Ann \& Kim, 2012; Tschannen-Moran \& Hoy, 2001).

Science teaching efficacy belief, on the other hand, bespeaks teachers' beliefs in their competencies regarding teaching science effectively and increasing students' achievements (Riggs and Enochs, 1990). Teachers with high level science teaching efficacy tend to employ student-centred approaches, allocate more time to science teaching, and adopt activities based on inquiry, whereas those with low level science teaching efficacy prefer transferring knowledge in the books, and embrace direct instruction methods seen as teacher-centred approaches (Savasci-Acikalin, 2013). There is a positive significant correlation between teachers' science teaching self-efficacy beliefs and their content knowledge in science (Menon and Sadler, 2016). In this sense, it is argued that their self-confidence on science teaching will boost if their science content knowledge in science is enhanced (Bleicher \& Lindgren, 2005; Morrell \& Carroll, 2003).

In a study by Hechter (2011), it has been accentuated that prospective teachers had low level self-efficacy beliefs in planning science courses. In another one by Kinskey (2018), prospective teachers' self-efficacy beliefs were examined through action research, and the author concluded that the participants had low level self-efficacy beliefs in managing the time and materials whilst teaching science. There have been few studies aiming at developing teachers or prospective teachers' self-efficacy beliefs in science teaching (Knaggs \& Sondergeld, 2015; Menon \& Sadler, 2016; Trauth-Nare, 2015; Avery \& Meyer, 2012). All students, including gifted/talented students need teachers who have 
higher levels of science teaching self-efficacy beliefs. Literature has revealed that very few publications are available that address the issue of boosting teachers or prospective teachers' self-efficacy beliefs in science teaching.

\subsection{Competence for Learning Science}

It is of great importance to bring up each individual with Science Literacy Skills to make them gain $21^{\text {st }}$ century skills and to enable them to be lifelong learners (Holbrook \& Rannikmae, 2007). The foundations of Science Literacy and Lifelong Learning are based on the development of scientific inquiry skills of individuals (Lederman, Lederman \& Antink, 2013). Scientific inquiry is considered as a significant means of high-quality science teaching (NSTA, 2014). The subdimensions of scientific inquiries have been conceptualized as presenting questions and hypothesis, planning, experimenting, and data gathering as well as data analysing, interpreting, and concluding (Chang, et al., 2011).

There have been some instruments developed to measure the teachers' and prospective teachers' competences for learning science. Among those is the scale developed by Chang et al. (2011) which includes 'Competence in Scientific Inquiry' and 'Competence in Communication' subscales. Another instrument to measure competences in science learning is 'the Inquiry Skills Scale' developed by Arnold, Bourdeau and Nott, (2013). Reaume (2011) developed 'the Inquiry Learning Skills Perception in Science', as well. In this sense, it can be suggested that the success of developing competences in science learning rests upon inquiry learning and scientific inquiry. Regarding this, O'Donnel (2011) argued that teachers lack knowledge and experience in maintaining courses based on inquiry, so they are not willing to embrace the teaching approaches based on inquiry and so fail to provide a qualified education. Within this perspective, it can be argued that studies intended to boost classroom teachers' competences for learning science such as scientific inquiry may yield fruitful results in providing all students with education based on their interests and needs, and gifted/talented are no exception.

\subsection{Outdoor Activities Performing Perceptions}

As in the case of average students, gifted ones also are curious about volcanoes, astronomical studies, engineering, archaeological excavations, and socio-scientific issues like world affairs (Silverman,1994; Vaivre-Douret, 2011), but their interests can be multidisciplinary (Kaplan, 2009; VanTassel-Baska and Brown, 2009). For example, along with having a deep interest in places such as Etna Volcano in Italy or Mayon volcano in the Philippines, they may be interested in areas such as the properties of the rocks, the climate of the volcano eruption, the properties of the carbon dioxide in the volcanoes and the properties of the other materials, the effect of the volcano on the geography and the people, as well. The fact that gifted students have keen interests in several disciplines, as well as their different interests in more than one discipline related to themes or situations in a discipline area indicates that these students need interdisciplinary and topic-based outdoor learning activities (Best, Dickinson, HugstadVaa Leer \& Kalina, 2017; Stephens \& Karnes, 2016; Nielsen \& Knudson, 1992). In a study by Benny and Blonder (2016), it has been found that interdisciplinary teaching practices benefit gifted students in the acquisition of $21^{\text {st }}$ century skills such as collaborative work, communication, critical and creative thinking, and problem solving (Renzulli, 2012). In this sense, it can be suggested that growing teachers who can perform outdoor teaching activities effectively in providing interdisciplinary learning of gifted students and developing their interests and potentials are essential. 
Current studies have dwelled upon several outdoor teaching applications such as museum, zoo or botanic park visits and their reflections on students. Existing research has focused on the effect of outdoor teaching activities on the attitudes of non-gifted students towards environmental issues (Carrier, Thomson, Tugurian and Stevenson, 2014), their environmental awareness (Fisman, 2005), cognitive and affective outcomes (Randler, et al. 2007), their attitudes towards science (Jarvis and Pell, 2005), out-ofschool nature experiences (Uitto, et al. 2006), interests towards science (Zoldosova and Prokop, 2006). In studies with teachers, it is seen that teachers' knowledge levels and their opinions on outdoor learning were investigated (Marentin ve Guisasola, 2009; Tsai, 2006). It is also seen when the knowledge levels of teachers were examined that the frequency of outdoor teaching activity changed according to the schools' area, and teachers found outdoor teaching opportunities as insufficient (Waite, 2009). The research revealed that most of the studies on outdoor teaching were conducted in science (AyotteBeaudet, Potvin, Lapierre and Glackin, 2017). In most of the studies carried out with teachers, it is seen that social/science teachers were mostly recruited as participants (Troxclair, 2000). On the other hand, in studies with classroom teachers, teachers mostly prefer using historical buildings, organizations and institutions as outdoor teaching environments, but less often visit art places or virtual platforms (Martín-Gutiérrez, Mora, Añorbe-Díaz, and González-Marrero, 2017).

There have been limited research on socializiation of gifted students in or out of the classroom and raising qualified classroom teachers (Archambault and ark., 1993; Callahan, Moon, Oh, et. al. 2015; Tomlinson et. al., 2003; Westburg et. al., 1993). In this study, whether the differentiated science teaching module designed for gifted students will impact the prospective teachers' outdoor science activities performing beliefs has been investigated through a mixed-research methodology.

\subsection{Academic Self-Efficacy}

Academic self-efficacy is conceptualized as one's belief in successfully accomplishing an academic task and is closely related to one's performance (Bong et. al., 2012). Pajares and Schunk (2001) suggest that academic self-efficacy impacts use of cognitive and metacognitive strategies as well as self-regulation process linked to these strategies. Academic self-efficacy belief is a strong predictor of academic achievement (Zajacova, Lynch and Espenshadet, 2005). There have been studies in which self-efficacy towards teaching of such subjects as science, Maths, and biology was analyzed as well as those in which researchers have focused on teachers' self-efficacies and their relationships with several variables (Sokmen, 2018). In one of those, Oguz (2012) found that the academic self-efficacy beliefs of first and second grade prospective teachers were at low level. In this sense, there is no research on the programmes intended to develop novice prospective classroom teachers' academic self-efficacy beliefs and their effects on prospective classroom teachers.

\section{Method}

\subsection{Research Design}

A concurrent embedded research design from mixed research methodologies was used in this study. In this research methodology, the additional procedures are applied to support the basic research design (Creswell, Klassen, Plano Clark, and Smith, 2011). In 
this research design, the qualitative data can be referred to alongside pre- and postapplications of the experimental procedure while evaluating the documents and basic information needed in experimental applications comprehensively in order to understand the participants, their environments, and the research phenomenon (Creswell and Plano Clark, 2014). The qualitative data helps a researcher to determine the sources which make the implementation easy, providing means of testing the validity of the quantitative data (Creswell, Fetters, Plano Clark and Morales, 2009). In this sense, the qualitative data were obtained before and after the experimental procedure. Thanks to the qualitative data, it was attempted to assess the education of prospective teachers through multi-techniques, examining if the qualitative data supports the quantitative data in the study.

\subsubsection{The Quantitative Dimension of the Research}

The quasi-experimental research design with pre- and post-control group from the experimental research designs was used in the quantitative part of the study. According to this research design, the participants are assigned to the groups not recruiting each of them randomly but assigning a group as the experimental and the other one is control group (Campell and Stanley, 1963). The independent variable in the study is the differentiated science teaching module, while (i) science teaching efficacy beliefs, (ii) competences for learning science, (iii) outdoor science activities performing beliefs and (iv) academic self-efficacies are dependent variables of the study. Table 2 summarizes the experimental procedure of the study.

Table 2 Experimental procedure

\begin{tabular}{|c|c|c|c|}
\hline \multirow{6}{*}{$\begin{array}{l}\text { Experimental } \\
\text { Group }\end{array}$} & Before the procedure & Procedure & After the procedure \\
\hline & $\begin{array}{l}\text { Competence for Learning } \\
\text { Science Scale (CSLS) }\end{array}$ & \multirow{4}{*}{$\begin{array}{l}\text { Differentiated } \\
\text { Science Teaching } \\
\text { Module (DSET) }\end{array}$} & $\begin{array}{l}\text { Competence for Learning } \\
\text { Science Scale (CSLS) }\end{array}$ \\
\hline & \multirow{2}{*}{$\begin{array}{l}\text { The Outdoor Science } \\
\text { Activities Performing Scale } \\
\text { (OLAS) }\end{array}$} & & $\begin{array}{l}\text { The Outdoor Science Activities } \\
\text { Performing Scale (OLAS) }\end{array}$ \\
\hline & & & $\begin{array}{l}\text { Academic Self-Efficacy Scale } \\
\text { (ASES) }\end{array}$ \\
\hline & $\begin{array}{l}\text { Academic Self-Efficacy Scale } \\
\text { (ASES) }\end{array}$ & & \multirow{2}{*}{$\begin{array}{l}\text { The Science Teaching Efficacy } \\
\text { Belief Scale (STEBI) }\end{array}$} \\
\hline & $\begin{array}{l}\text { The Science Teaching } \\
\text { Efficacy Belief Scale (STEBI) }\end{array}$ & & \\
\hline
\end{tabular}

\subsubsection{The Qualitative Dimension of the Research}

The case study research design was adopted in the qualitative dimension of the study. The elements of the case (context, people, events, process, etc.) are examined in a holistic way in this methodology (Patton, 2014). The reason why this methodology was employed is that it allows researchers to delve into one or more cases in detail through different data collection techniques. The students' opinions on the trainings and the effectiveness of the learning tools were attempted to examine in the qualitative dimension of the study. The structured-interview method (Seidman, 2012) was used before the procedure to determine the opinions of the participants, while the document analysis technique (Rapley, 2007) was employed to reveal their opinions following the procedure.

\subsection{Participants}

The participants were 69 sophomore students studying in the Division of Classroom Education in the Department of Elementary and Early Childhood Education 
in the Faculty of Education in Amasya University and attending the Science and Technology Laboratory course during the fall term of the 2018-2019 academic year. The participants were randomly selected for the control and the experimental groups from the 2nd grade students, and those involved in the experimental group who volunteered to take part in the procedure. The experimental group consisted of 32 prospective teachers, while 37 participants were in the control group. There were 26 female participants and 6 male participants in the experimental group, while the control group included 27 female and 10 male participants. Further, the participants' age ranges were between 20 and 25 years in the experimental group and 20 and 26 in the control group.

\subsection{Data Collection Instruments}

\subsection{The Outdoor Science Activities Performing Scale (OLAS)}

Developed by Karademir and Erten (2013), this scale is aimed at measuring the prospective teachers' perceptions towards the outdoor education activities and their actions related to them. The reliability coefficients of the subdimensions of the scale varied from .89 to .95 (Karademir \& Erten, 2013). The scale includes 50 items and six sub-scales (Behavioural Expectations, Behavioural Evaluations, Person, institutions or industries, Motivation, Behavioural Difficulties, Behavioural Easies). In this study, the reliability coefficient of the OLAS was found as .85.

\subsection{Academic Self-Efficacy Scale (ASES)}

Developed by Owen and Froman (1988) and adapted into Turkish by Ekici (2012), this scale is aimed at measuring prospective teachers' academic self-efficacies. Including 33 items, this scale consists of three sub-scales as follows: (1) overt, social situations, (2) cognitive operation and (3) technical skills. The reliability coefficient of the scale was found as .86 (Ekici, 2012). In this study, the reliability coefficient of the ASES was found as .81.

\subsection{The Science Teaching Efficacy Belief (STEBI)}

Developed by Riggs and Enochs (1990) and adapted into Turkish by Ozkan Tekkaya and Çakıroglu, (2002), this scale is aimed at measuring prospective teachers' Science Teaching Efficacy Beliefs. Including 23 items, the STEBI consists of two subscales: personal science teaching efficacy beliefs (13 items) and science teaching outcome expectancy (10 items). The reliability coefficient of the scale was found as .76 (Ozkan Tekkaya and Cakiroglu, 2002). In this study, the reliability coefficient of the STEBI was found as .79.

\subsection{The Competence Scale for Learning Science (CSLS)}

Developed by Chang et al. (2011) and adapted into Turkish by Senler (2014), this scale is aimed at measuring students' competence in learning science, as well as scientific inquiry and communication skills. Including 29 items, the Competence Scale for Learning Science is comprised of two subscales as follows: (1) scientific inquiry scale (14 items), and (2) communication scale (15 items). The reliability coefficient of the scale was found as .93 (Senler, 2014). In this study, the reliability coefficient of the CSLS was found as .94 . 


\subsection{The Structured Interview Form}

Including five open-ended questions, a structured interview form prepared by the researcher was employed to collect the qualitative data. A field expert was asked to review the draft version of the form in terms of suitability of the questions for the purpose of the research and comprehensibility. Additionally, following the revision of the form, a prospective teacher was asked to answer the questions. The final version of the form was designed, and the form was sent to the participants in written form.

\subsection{Reflections}

Following the differentiated experimental procedures conducted by pre-service teachers with students in primary schools within the scope of DSET applications, the reflections through which pre-service teachers expressed their opinions on the activities were used as data collection tools.

\subsection{Procedures}

\subsubsection{Differentiated Science Teaching Module (DSET) for Prospective Techers}

The purpose of designing this module was to allow prospective classroom teachers to get information about different methods and techniques that can be used in gifted/talented education, and to help them develop their content knowledge on science. Based on a literature review (Tomlinson 2004; Renzulli, 2012; Freeman, 2012; VanTassel-Baska and Stambaugh, 2005; Nielsen and Kudson, 1992), the theoretical framework was formed while designing DSET. Following this, semi-structured interviews were conducted with 5 classroom teachers who had gifted/talented students in their classrooms. The classroom teachers were asked to express their needs and expectations from DSET applications and mentioned that they need education on using DSET applications in planning the outdoor learning activities and evaluations. In line with the findings, a differentiated Science Teaching Module for Teachers has been designed for prospective teachers (VanTassel-Baska and Brown, 2009; Renzulli et. al., 2007; Akar, 2015; Harlen, 2001).

The DSET applications are comprised of two stages. In the first one, such themes as individual differences, the characteristics of gifted students, differentiated teaching and outdoor learning subjects were organized. Table 3 summarizes the information on the first stage of the applications.

Table 3 Information's about the differentiated science teaching module

\begin{tabular}{llllll}
\hline Content & $\mathbf{1}^{\text {st }}$ Week & $\mathbf{2}^{\text {nd }}$ Week & $\mathbf{3}^{\text {rd }}$ Week & $\mathbf{4}^{\text {th }}$ Week & $\mathbf{5}^{\text {th }} \mathbf{W e e k}$ \\
& $\begin{array}{l}\text { differences } \\
\text { and learning }\end{array}$ & $\begin{array}{l}\text { Characteristics and } \\
\text { integration of gifted } \\
\text { students }\end{array}$ & $\begin{array}{l}\text { Differentiated } \\
\text { education } \\
\text { dimensions }\end{array}$ & $\begin{array}{l}\text { Outdoor } \\
\text { learning }\end{array}$ & $\begin{array}{l}\text { Duties } \\
\text { responsibility on } \\
\text { primary teachers }\end{array}$ \\
\hline Method & Cooperative Learning & & \\
\hline $\begin{array}{l}\text { Strategies, } \\
\text { materials }\end{array}$ & $\begin{array}{l}\text { Worksheets, Research projects, Virtual trips, Brainstorming, Mind map, Videos and } \\
\text { pictures, Individual and group work }\end{array}$ & & & \\
\hline Evaluation & Metaphors & & & \\
\hline
\end{tabular}

During the second stage of the application, a four-weeks application that is in line with the content of science course in primary school was conducted to develop prospective 
teachers' science content knowledge and make them acquire different method and techniques in differentiation. These applications were conducted within the scope of Science and Technology Laboratory Course. The participants were provided with the information on how the experiments can be differentiated for gifted students during the applications as well as examples. Following the experimental procedures, weekly performance tasks and rubrics were given to the participants to allow them to make self and peer assessments. The outcomes of the performance tasks were evaluated by the researcher and feedback was given. At this stage, it was attempted to enable prospective teachers to determine problems in science for gifted in the Science laboratory, to detect dependent and independent variables and to develop scientific skills while conducting experimental processes. The participants designed experiments on physics, chemistry and biology stations and conducted differentiated activities with students in three primary schools in various sections of the procedure. Figure 1 summarizes the second stage.

Figure 1 Information on the DSET applications for prospective teachers

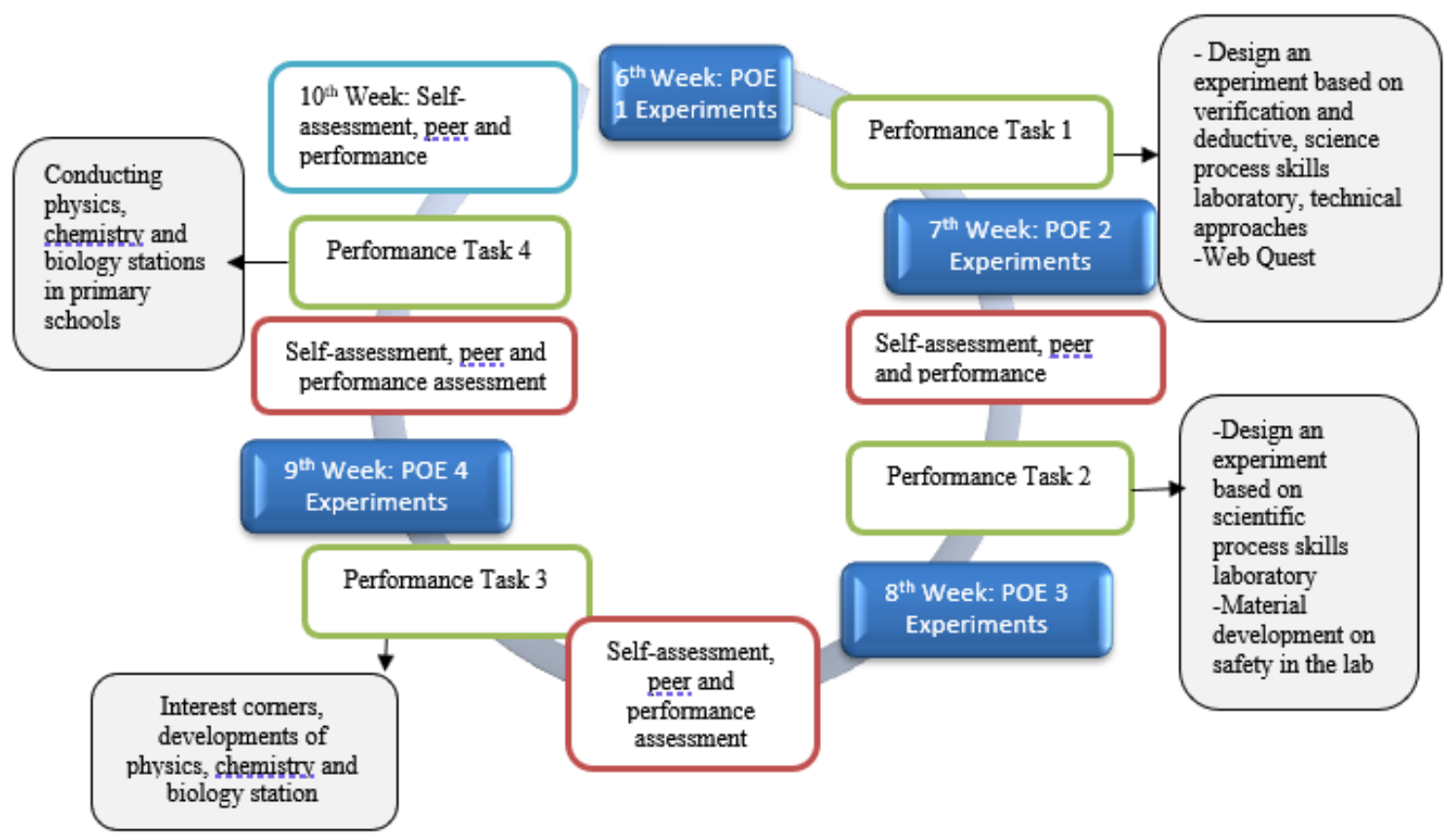

The DSET applications lasted for ten weeks in total: First stage activities (five weeks) and second stage activities (five weeks). The prospective classroom teachers were surveyed through pre-test instruments for the quantitative data before the procedure. The reflections through which prospective teachers expressed their opinions on the activities were used as qualitative following the procedure, post-tests were conducted as quantitative data collection tools and structured interview forms were given to the participants to get the qualitative data.

\subsubsection{The Procedure in the Control Group}

The Science and Technology Laboratory course given in the Division of Classroom Education in the Department of Elementary and Early Childhood Education in the Faculty of Education in Amasya University is conducted through the POE (PredictObserve-Explain) approach in all classes. In this research, self and peer assessments, and 
science teaching activities enriched with performance tasks were included in the experimental group, whereas there was no differentiated activity in the control group. The researcher analysed the experiment reports based on POE to track the applications in the control groups to check whether there was any differentiation or not. The pre-and posttest measurements were tried to be performed simultaneously as in the experimental groups.

\subsection{Data Analysis}

For the analysis of the quantitative data, the SPSS 21.0 software was employed. Test assumptions: Shapiro Wilk and Kolmogorov Simirnov tests were carried out to test the normality of the data from the pre-test measurements. Table 4 summarizes the distribution of the data obtained from the pre-test measurements.

Table 4 Normality distributions of the data obtained from pre-test measurements

\begin{tabular}{lllllll}
\hline \multirow{2}{*}{ Scales } & \multicolumn{2}{l}{ Kolmogorov-Smirnov } & \multicolumn{5}{c}{ Shapiro-Wilk } \\
\cline { 2 - 7 } & Statistic & Sd & P & Statistic & Sd & P \\
\hline CSLS &, 176 & 67 &, 000 &, 847 & 67 &, 000 \\
\hline OLAS &, 067 & 67 &, $200^{*}$ &, 987 & 67 &, 686 \\
\hline ASES &, 103 & 67 &, 073 &, 954 & 67 &, 015 \\
\hline STEBI &, 074 & 67 &, $200^{*}$ &, 971 & 67 &, 113 \\
\hline
\end{tabular}

As shown in Table 4, it is seen that the significance levels of all variables except CSLS were above 0.05 according to the Kolmogorov-Smirnov test, which means that the data set had a normal distribution. Based on these findings from the variables in the subscales, parametric tests were employed in the variables with normal distribution, whereas nonparametric tests were used in the variables which did not show normal distributions.

\subsubsection{The Reliability and Validity in the Research}

In order to get more information on the dependent variables in the research, both quantitative and qualitative data collection instruments were employed and then the obtained data were compared. The reliability coefficients of the quantitative data collection tools were calculated and reported. The reliability coefficients of the scales were found at least .79. The quantitative assumptions for each variable were considered, and the testing for the normality of data was conducted. In this sense, parametric and nonparametric tests were employed according to the distribution of the data. For the analysis of the qualitative data, a field expert was asked to conduct coding for the rigor of the qualitative data. The consistency which was measured between coders was calculated as .82, which is based on the Miles and Huberman' formula (1991). The photos taken and students' tasks are stored.

\subsubsection{Trustworthiness}

In this research, the typology suggested by Lincoln and Guba's (1985) was used to ensure trustworthiness. In this sense, four criteria were considered as credibility, transferability, dependability, and confirmability. In terms of credibility, the data were collected before and after the procedure. Further, credibility was addressed such activities such as prolonged engagement and member checking. Given the transferability, thick descriptions with participants' own statements are presented in the qualitative findings. In this study, the details about the context of the study in terms of the data collection 
process were explained. For the dependability, the procedures are explained in detail. When it comes to confirmability, the reasons for theoretical, methodological, and analytical choices throughout the entire study were included to address the confirmability (Koch, 1994). Further, the findings of this research are in line with the previous literature.

\section{Findings}

\subsection{Tests for Comparing Pre-test Scores (Hypothesis 1, 4, 7 and 10)}

Based on the findings, it is seen that the pre-test scores of the prospective teachers' OLAS, ASES and STEBI show normal distributions (Table 4). For this reason, the parametric tests were used in the analysis of the pre-test data on the variables. The pretest scores of the CSLS did not have normal distribution, Mann Whitney U test from nonparametric tests was used for the analysis of the pre-test scores in this scale. Table 5 summarizes results on the pre-test scores of the dependent variables.

Table 5 The independent samples t-test results on the pre-test scores of the dependent variables

\begin{tabular}{|c|c|c|c|c|c|c|c|c|}
\hline & Scales & Pre-test & $\mathbf{N}$ & Mean & Ss. & Sd & $\mathbf{T}$ & $\mathbf{P}$ \\
\hline \multirow{6}{*}{$\begin{array}{l}\text { Independent } \\
\text { sample t-test }\end{array}$} & OLAS & Experimental & 32 & 5,42 & ,88 & 67 & 0,310 & 0,758 \\
\hline & & Control & 37 & 5,37 & ,49 & & & \\
\hline & ASES & Experimental & 32 & 3,21 & ,56 & 66 & $-0,284$ & 0,777 \\
\hline & & Control & 37 & 3,24 &, 45 & & & \\
\hline & STEBI & Experimental & 32 & 3,25 & ,53 & 67 & $-1,175$ & 0,244 \\
\hline & & Control & 36 & 3,39 & ,48 & & & \\
\hline \multirow{2}{*}{$\begin{array}{l}\text { Mann } \\
\text { Whitney U } \\
\text { test }\end{array}$} & & Groups & $\mathbf{N}$ & Mean rank & $\begin{array}{l}\text { Sum of } \\
\text { ranks }\end{array}$ & Sd & $\mathbf{U}$ & $\mathbf{P}$ \\
\hline & CSLS & Experimental & 32 & 1,88 & $\begin{array}{l}, 39 \\
62\end{array}$ & 67 & $-2,384$ & 0,020 \\
\hline
\end{tabular}

As shown in Table 5, there are no statistically significant differences among the variables OLAS, ASES, STEBI and CSLS between the pre-test scores of the control and the experimental groups $(\mathrm{p}>0,05)$.

\subsection{Tests for Comparing Post-test Scores (Hypothesis 2, 5, 8 and 11)}

Based on the findings, it is seen that the post-test scores of the prospective teachers' OLAS, ASES and STEBI show normal distributions. For this reason, the independent samples t-test was used for the analysis of post-test scores of the scales. The post-test scores of the CSLS did not have normal distribution, Mann Whitney U test from nonparametric tests was used for the analysis. Table 6 summarizes results on the post-test scores of the dependent variables.

Table 6 Summary of the independent samples t-test results on the post-test scores of the dependent variables

\begin{tabular}{llllllllll}
\hline & Scales & Post-test & N & Mean & Ss. & Sd & T & P & $\begin{array}{l}\text { Cohen's } \\
\text { Effect Size }\end{array}$ \\
\hline \multirow{3}{*}{$\begin{array}{llllllll}\text { Independent } \\
\text { sample t-test }\end{array}$} & OLAS & Experimental & 32 & 5,83 &, 18 & 67 & 5,512 & $\mathbf{0 , 0 0 1 *}$ & 1,39 \\
& & Control & 37 & 5,30 &, 52 & & & & \\
\cline { 2 - 9 } & ASES & Experimental & 32 & 4,29 &, 37 & 67 & 12,414 & $\mathbf{0 , 0 0 0} *$ & 3,01 \\
& & Control & 37 & 3,17 &, 37 & & & & \\
\hline
\end{tabular}




\begin{tabular}{|c|c|c|c|c|c|c|c|c|c|c|}
\hline & & & Control & 37 & 2,48 & ,41 & & & & \\
\hline \multirow{3}{*}{$\begin{array}{l}\text { Mann } \\
\text { Whitney } \\
\text { test }\end{array}$} & \multirow{3}{*}{\multicolumn{2}{|c|}{$\mathrm{U}$}} & Groups & $\mathbf{N}$ & Mean & Ss. & Sd & $\mathbf{U}$ & $\mathbf{P}$ & $\begin{array}{ll}\text { Cohen's } & \text { d } \\
\text { effect size }\end{array}$ \\
\hline & & & Experimental & 32 & 4,12 &, 16 & 67 & 13,008 & 0,000* & 3,25 \\
\hline & & & Control & 37 & 2,34 & ,75 & & & & \\
\hline
\end{tabular}

As shown in Table 6, there are statistically significant differences among the variables OLAS, ASES, STEBI and CSLS between the post-test scores of the control and the experimental groups in favor of the experimental group $(p<0,05)$. Cohens' $d$ effect size was calculated to measure the effect sizes during the analysis. According to Cohen (1988), the effect size value represents a small effect size of less than 0.20 and a medium effect level of 0.50 and above (Ustun and Eryilmaz, 2014).

\subsection{Tests for Comparing Pre and Post-test Scores (Hypothesis 3, 6, 9 and 12)}

For the comparison of the pre-and post-test scores of the participants in the experimental group in terms of The Outdoor Science Activities Performing Scale and The Academic Self-Efficacy Scale, dependent samples t-test was used. Since the data set show normal distribution, parametric tests were used. Table 7 summarizes the dependent samples t-test results of the pre and post test scores from the variables.

Table 7 Summary of the dependent samples t-test results on the pre-and post-test scores of the dependent variables

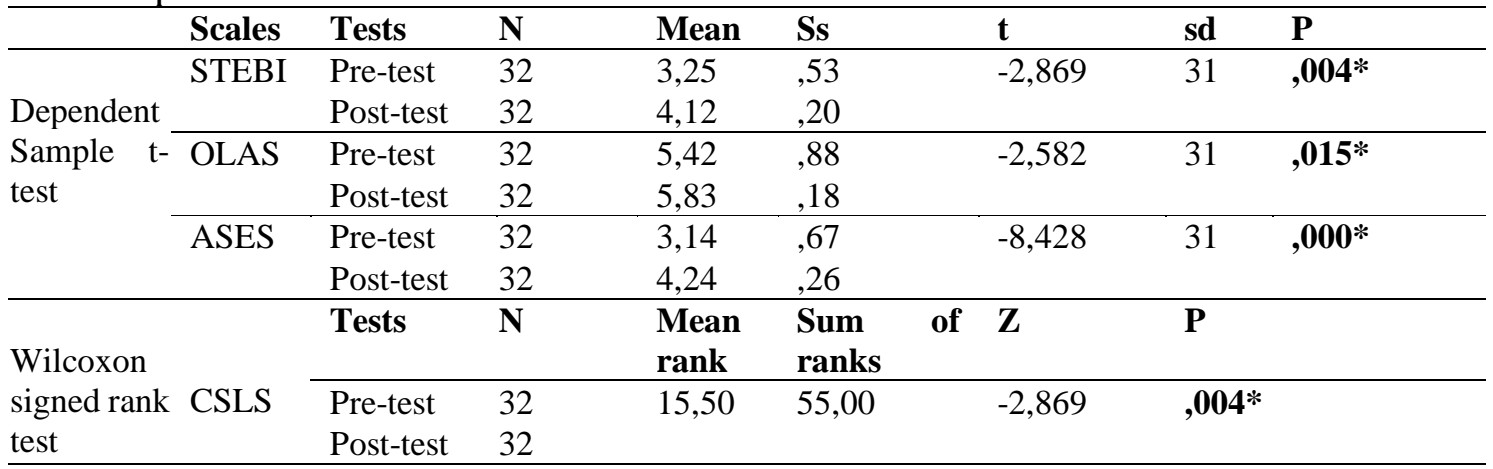

As shown in Table 9, there is statistically significant difference between the pre-and posttest scores of the participants in the experimental group in terms STEBI, OLAS, ASES. There is statistically significant difference between on the CSLS pre-and post-test scores of the experimental group $(\mathrm{p}<0,05)$. 
Table 8 Prospective Classroom Teachers' Opinions on DSET Applications

Theme Science Teaching Efficacy Belief and the Competence for Learning Science

T5: The DSET applications developed my science teaching efficacy belief. I got more information on the science teaching. For instance, I acquired new information on the fact that I am able to take my students to such places as forests, zoos, botanic parks while studying on the unit 'Let's Know about the Living Beings', and how I can design and assess these activities. It added to my competence for learning science, as well. Additionally, we acquired skills on performing experiments and observations in the laboratories..

T9: I had prejudices towards science before and didn't have competence in science teaching. I adopted a positive attitude towards science thanks to the DSET applications and activities. Lab activities contributed to my self-confidence, as well.

T14: I discovered lots of things while examining then on my own. The applications developed both my cognitive skills and psychomotor skills. They helped me think in-depth. I grasped such processes as formulating a hypothesis, determining variables and conducting experiments, observation, assessments and explanations.

T8: I noticed that my concept knowledge in science isn't satisfactory and so I started to read more books in science"

T23: I gained new experiences related to the relationship between me and the students. I was able to

Findings on assess my science content knowledge and see whether the it is adequate or not. I tried to compensate my Reflections shortcomings when I check my content knowledge during the experiments and activities. The DSET applications demonstrated me that my science content knowledge is needed to be developed, and I had difficulty in teaching during the courses.

\section{Performing Belief}

T: I got new information on what I can do outside the classroom, and noticed the contributions of the DSET activities to the students' learning. Thanks to this, I have more self-confidence in the activities I can design.

T17: I strongly support the outside teaching activities. I believe that the applications have added much to our understanding on the issue and I think I will provide my students with better activities.

T19: The activities and applications helped me to carry out the outdoor teaching activities properly.

T30: The applications brought a new perspective on the DSET activities. I got different ideas and opinions. I think I will be able to put these innovative ideas into practice when I begin to teach.

T21: The fact that we were provided with heoretical information about the activities before the practices added much to ou understanding. I had no information on how

can develop and assess an outdoor activity.

In this sense, the applications were very beneficial for us.

T5: Following the applications, I noticed the positive changes in me. I felt like that I am more into the teaching profession. This inspiring experience indicated my shortcoming as a future teacher, promoted me to work harder for self-development and stimulated me that I will educate our future when I begin to teach.
Academic Self-Efficacy Beliefs

13: I think the applications develope my academic self-efficacies. Thanks to
these, I will be able to command the these, I will be able to command the and provide my future students with high-quality education.

T10: The procedure enabled me to think systematically. My creativity and horizon developed.

T22: I think I stand one more step ahead from those who haven't participated in such an activity, and the application guided me in terms of my future career. The activities boosted my learnin wareness and science learning proces skills. I am able to adopt these new learnings into my academic skills an implement them.

22: What I loved most was that the applications encouraged us to work actively. For example, we decided to work collaboratively while we were determining what we could do in group and performed the activities.

T18: The activities and experiments $w$ conducted when we visited the school were unique experiences for me. I had innovative ideas and learned to desig different experiments and activities through limited materials. The interactions between the students and me were also inspiring for me as to the teaching profession.
Occupational

Confidence

T3: The DSET application

increased my teache consciousness. I think I will not oscillate and falter when I begin to teach. This is because the ideas emerging from the procedure will guide me.. They will inspire me in the future I think.

T17: Before the applications, I had no idea on what I should do with my students with special conditions or about from whom I can ask for help. However, Ihave clear idea on these issues now. The activities developed my professional skills.

T22: I noticed the importance of these kinds of activities following the procedure. I felt that I have increased self-awareness of teaching profession.

T3: I think this procedure has fully developed me in teaching profession. This is because I was responsible for the planning and preparations. Thi increased my selfresponsibility and selfconfidence. 


\subsection{Prospective Classroom Teachers' Opinions and Reflections on DSET Applications}

The findings obtained through the structured interviews were categorized under five subtitles as follows: $(i)$ the competence for learning science and science teaching efficacy belief, (ii) perceptions towards the outdoor science teaching activities performing, (iii) the academic self-efficacy belief, and (iv) the effect of occupational self-confidence. The opinions are presented through the participants' own expressions as Table 8.

Most of the participants expressed that the applications contributed to their professional developments and pedagogical content knowledge. There are expressions highlighting that the science activities with children during the DSET applications helped them to gain selfregulation as well as to have high levels of self-confidence. The perceptions of the prospective teachers about the concepts such as "individual difference, gifted/talented, differentiated science teaching and outdoor learning" were coded and the findings are presented in Table 9.

Table 9 Findings on the reflections

\begin{tabular}{|c|c|c|c|c|}
\hline Concepts & Individual Difference & $\begin{array}{l}\text { Gifted/ } \\
\text { Talented }\end{array}$ & $\begin{array}{l}\text { Differentiated } \\
\text { Teaching }\end{array}$ & Outdoor Learning \\
\hline $\begin{array}{l}\text { The } \\
\text { point(s) } \\
\text { mentioned } \\
\text { in the } \\
\text { definitions }\end{array}$ & $\begin{array}{l}\text { Different interest/talent } \\
\text { (T1,T6,T7,T16,T17,T20, } \\
\text { T21,T5,T30) } \\
\text { Different } \\
\text { preferences } \\
\text { (T3,T8,T5,T6,T12,T19) } \\
\text { Different cognitive traits } \\
\text { (T9,T23, T2, T13, T21, } \\
\text { T22,T31) } \\
\text { Physical differences (T4, } \\
\text { T9, T14, T15) } \\
\text { Emotional differences } \\
\text { (T10, T4, T23) } \\
\text { Different learning needs } \\
\text { (T6, T19) } \\
\text { Personal characteristics } \\
\text { (T11) } \\
\text { Different intelligence } \\
\text { (T15, T10) } \\
\text { Individual development } \\
\text { (T10) }\end{array}$ & $\begin{array}{l}\text { Having talents in one } \\
\text { or more fields (T3, } \\
\text { T6, T7, T9, T10, T12, } \\
\text { T17, T18) } \\
\text { High-level learning } \\
\text { when compared to } \\
\text { peers (T8, T19, T22, } \\
\text { T23) } \\
\text { Being able to use the } \\
\text { intelligence actively } \\
\text { (T1, T 13, T5,T2,T31) } \\
\text { creativity skills } \\
\text { (T11,T16,T30) } \\
\text { Knowing the theme in } \\
\text { detail (T4, T21) } \\
\text { High achievements in } \\
\text { some fields (T12, } \\
\text { T14) } \\
\text { Having high level of } \\
\text { intelligence (T15) }\end{array}$ & 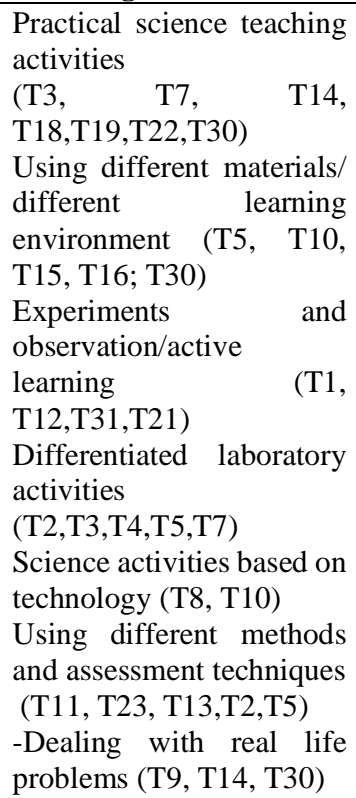 & $\begin{array}{l}\text { Extensive research } \\
\text { (T23) } \\
\text { Independent learning } \\
\text { (T1,T2,T3,T9,T17T22, } \\
\text { T31) } \\
\text { Flexible time (T21, T4) } \\
\text { Tangible learning (T30, } \\
\text { T14, T15,T16, T18) } \\
\text { Maintaining being } \\
\text { motivated (T30) } \\
\text { Learning based on } \\
\text { excursions and } \\
\text { observations } \\
\text { (T6,T10,T18, T30) } \\
\text { Active learning (T13, } \\
\text { T12,T19) } \\
\text { Inquiry-based learning } \\
\text { (T10, T8) } \\
\text {-Discovering (T5) }\end{array}$ \\
\hline
\end{tabular}

\section{Discussion and Conclusion}

This study has sought to examine the effects of the DSET applications on the prospective classroom teachers in terms of some variables through a mixed-method research design. The discussions and conclusions on the findings related to the variables are presented in this section.

\section{The Science Teaching Efficacy Belief and the Competence for Learning Science}

Based on the findings from the statistical analysis, the hypotheses 1, 2 and 3 which focus on the effect of the DSET Module on the Science Teaching Efficacy Belief and the hypotheses 4, 5 and 6 (Tables 5, 6 and 7) which are directed to the effect of the DSET Module on the Competence for Learning Science have been supported. These results show that the DSET applications have a positive effect on The Science Teaching Efficacy Beliefs and the 
Competences for Learning Science of the prospective classroom teachers. That is to say, the DSET applications contributed to these skills and competences of the participants. According to the findings emerging from the semi-structured interviews and the reflections, the participants in the experimental group expressed that the applications helped them to regulate their science learning, and so have more interests towards science. They also had the means of developing their science process skills. Some of the participants in the experimental group mentioned that they were able to feel the reality of science thanks to the applications and their inquiry skills have also been developed. The qualitative findings concurred well with the quantitative data. One explanation on these findings may be the fact that the prospective classroom teachers participating in the study may have developed their science teaching efficacy beliefs by making them more active through performance tasks on the experiment types such as inquiry, inductive, scientific process skills, and technical approaches to develop their science pedagogical content knowledge. Additionally, designing materials in science during the applications, performing experiments with primary school students in physics, chemistry, and biology stations, and increasing their knowledge about the science concepts may have developed the competence for learning science of the participants. The fact that the participants were provided with several examples on each science subject during the first stage of the DSET applications, and the fact that the participants were shown videos on science teaching as well as the introduction of the Schoolyard programs may have boosted their competence for learning science.

The findings from the qualitative and the quantitative data corroborated with the previous research which have revealed that the applications based on the performance tasks and portfolios develop prospective teachers' science course achievements and the retention of them, worries, self-efficacies and life skills (Slater, 1991). In one of these, Menon and Sadler (2016) revealed a statistically positive relationship between the science teaching efficacy belief and science content knowledge. On the other hand, in another one, Ciray Ozkara and Guven (2018) concluded that science and technology laboratory applications cannot fully satisfy the needs of the prospective classroom teachers in terms of such skills as scientific inquiry. In this study, the prospective classroom teachers' science teaching efficacy beliefs may have developed through the activities based on the development of science pedagogical content knowledge. What is more, some positive contributions in the self-efficacy beliefs of the participants may have derived from the following the periodicals on science teaching, science and technology as well as discussions held in the classroom. In some part of the study, the DSET applications conducted in a village school, the prospective classroom teachers may have developed more self-confidence thereby boosting their science teaching efficacies, by interacting with primary school students. In this sense, positive mastery experiences can be an important source of developing the self-efficacy (Bandura, 1977).

\section{The Outdoor Science Activities Performing Beliefs}

Based on the findings from the statistical analysis, it can be said that the hypotheses 7 , 8 and 9 (Tables 5, 6, and 7) which focus on the effect of the DSET Module on the outdoor science activities performing beliefs have been supported. These results show that the DSET applications developed the prospective teachers' outdoor science activities performing beliefs. The quantitative findings obtained in this study have been supported by the qualitative data on the conceptual awareness of the students (Table 9). The prospective teachers expressed that the DSET applications contributed to their self-confidences in designing and assessing outdoor science teaching activities. According to the findings from the qualitative and the quantitative data, it can be concluded that the DSET applications develop the prospective classroom 
teachers' attitudes and beliefs in terms of designing differentiated learning environments for the outdoor science teaching in primary schools.

The basic philosophy of the DSET applications is based on the idea which considers the individual differences in a classroom and advocates that these applications allow teachers to integrate the gifted/talented students in regular classrooms, to satisfy their learning needs and thereby developing their potentials and interests, and providing the non-gifted students with enriched learning environments. The outdoor learning, namely extracurricular activities have become one of the most important elements of education today in that it is of great importance that all primary school students, regardless of giftedness, must develop their $21^{\text {st }}$ century skills, one of the fundamentals in achieving the targets of 2020 Vision Document, issued by Ministry of National Education in Turkey. During the procedure in the DSET applications, the participants may have had positive experiences in the theoretical and practical activities as well as during virtual excursions and may have developed positive attitudes and beliefs towards the outdoor teaching activities. It is thought that the tasks on the designing individual and group outdoor teaching activities carried out during the first stage of the DSET applications may have appealed to the participants. As an explanation for this finding, it can be noted that the participants may have been encouraged by the frequent inclusion of the examples on the DSET applications from the literature. They may have been motivated by the fact that they can succeed as long as they increase their science pedagogical content knowledge. Previous research has revealed that teachers find the outdoor teaching activities as appealing and indispensable, but they have difficulty in designing and assessing these activities (Ayotte-Beaudet, Potvin, Lapierre and Glackin, 2017; DeWitt and Osborne, 2007). Yildirim and Ozyilmaz Akamca (2017) argue that less has been said on the material design and developing methods/techniques in outdoor teaching. The fact that the participants were provided with the education on the designing activity for the outdoor teaching, planning the content and assessment methods may have contributed to their efficacies and beliefs. In this sense, Carrier, Thomson, Tugurian and Stevenson (2014) assert that it is of most importance to grow teachers who will be able to carry out outdoor teaching activities to boost students' interests and potentials and to achieve multidisciplinary learnings for the gifted/talented.

Previous research, on the other hand, has revealed that there have been some challenges in effective planning of the outdoor learning applications (DeWitt and Osborne, 2007). AyotteBeaudet, Potvin, Lapierre and Glackin (2017) concluded that teachers did not have sufficient knowledge and skills in outdoor teaching activities, and teachers from different branches did not conduct the outdoor teaching activities based on scientific inquiry. In this study, the reason why the participants in the control group did not have the same attitudes towards the outdoor science teaching performing as much as those in the experimental group may be their lack of education on the outdoor science teaching. The findings of the study by Chowdhury (2016) lend support to this study. The authors also concluded that the prospective teachers did not have sufficient knowledge and skills on outdoor teaching activities. In this sense, it can be noted that the promoting the prospective classroom teachers' knowledge and skills in terms of outdoor teaching would be beneficial for individual developments of both gifted and nongifted students as well as boosting their potentials in the DSET applications.

\section{Academic Self-Efficacy}

Based on the findings from the statistical analysis, it can be said that the hypotheses 10 , 11 and 12 (Tables 5, 6 and 7) which focus on the effect of the DSET Module on the academic self-efficacy have been supported. These results show that the DSET applications developed 
the prospective teachers' academic self-efficacy beliefs. From the findings obtained from the qualitative data, the prospective classroom teachers think that the DSET applications increased the participants' learning awareness, developed their critical thinking skills, and develop their self-efficacies through making connections with other courses. Academic self-efficacy is a concept that consists of social status, cognitive applications, and technical skills. The findings from the qualitative and the quantitative data show that the DSET applications developed the academic self-efficacy. As an explanation for this, it can be noted that the participants' academic self-efficacy may have been positively affected by the applications during the second stage of the DSET Module and teaching primary pupils through performing experiments in village schools. The prospective teachers developed their cognitive skills through portfolio tasks and produced authentic outcomes. The participants may have also recognized their own potentials through self and peer assessments and may have regulated their activities. What is more, following the self and peer assessments, the fact that the researcher examined the outcomes based on the assessment criteria and provided the participants with weekly feedback may have developed the self-efficacies of the participants. During the DSET applications, the participants visited the village schools to conduct experiments with the primary school students and acquired more experience through the activities conducted during the stations. All these activities may have boosted the academic self-efficacies of the prospective teachers.

\section{Concluding Remarks}

This study, designed as a mixed-method research, has revealed that the DSET applications develop the prospective classroom teachers' outdoor science activities performing beliefs, academic self-efficacies, competences for learning science, and science teaching efficacy beliefs. Based on the findings from the study, it can be noted that the DSET applications contribute to the individual and professional developments of the prospective classroom teachers. Among the findings are the fact that the applications increase the conceptual awareness of the participants in terms of individual difference, gifted/talented, differentiated teaching, and outdoor learning. The findings of this research corroborated with the previous literature concluding that the differentiated science teaching activities contribute to teachers and prospective teachers (Emir and Yaman, 2017; Borders, Woodley and Moore, 2014; Heacox, 2002).

\section{Limitations and Recommendations for Future Research}

This research has limitations in terms of the scales and structured interview forms. In this sense, the fact that observations and in-depth interviews could not be conducted is seen a limitation. This leads to some difficulties in determining the disadvantages of DSET. To overcome this limitation in the future studies, it can be suggested that DSET applications can be disseminated in the Division of Classroom Education, and their pros and cons can be observed.

It is important for prospective classroom teachers to have knowledge and skills on developing different such materials as concept maps, diagnostic branched trees, and semantic feature analyses; taking opinions of experts in such fields as physics, chemistry, and biology, and collaborating with experts to be able to perform the DSET applications effectively. In this sense, during the Special and Inclusive Education course, it would yield fruitful results to focus on the design and assessment of the differentiated teaching activities for the inclusion of gifted students as well as to introduce the planning of virtual excursions and preparing outdoor teaching activity materials. 


\section{Acknowledgements}

A part of this study was presented as an oral presentation at International Conference on Science, Mathematics, Entrepreneurship and Technology Education (2019).

\section{References}

Akar, I. (2020). Consensus on the competencies for a classroom teacher to support gifted students in the regular classroom: A delphi study, International Journal of Progressive Education, 16(1), 67-83. https://doi.org/10.29329/ijpe.2020.228.6

Archambault, F. X., Brown, S., Hallmark, B. W. Zhang, W. \& Emmons, C. (1993). Regular classroom practices with gifted students: results of a national survey of classroom teachers, The National Research Center On The Gifted And Talented, The University of Connecticut Storrs, Connecticut. https://nrcgt.uconn.edu/wpcontent/uploads/sites/953/2015/04/rm93102.pdf

Arnold, M. E., Bourdeau, V. D. \& Nott, B. D. (2013). Measuring science inquiry skills in youth development programs: The Science Process Skills Inventory, 8(1), 515.https://doi.org/10.5195/jyd.2013.103

Avery, L. M., \& Meyer, D. Z. (2012). Teaching science as science is practiced: Opportunities and limits for enhancing preservice elementary teachers' self-efficacy for science and science teaching. School Science and Mathematics, 112, 395-409. https://doi.org/10.1111/j.1949-8594.2012.00159.x

Ayotte-Beaudet, J. P., Potvin, P., Lapierre, H. G. \& Glackin, M. (2017). Teaching and learning science outdoors in schools' immediate surroundings at K-12 levels: A meta-synthesis, Journal of Mathematics Science and Technology Education, 13(8), 5343-5363. https://doi.org/10.12973/eurasia.2017.00833a

Bandura, A. (1977). Self-efficacy: Toward a unifying theory of behavioral change. Psychological Review, $\quad 84(2), \quad$ 191-215. https://doi.org/10.1037/0033295X.84.2.191

Bandura, A., \& Adams, N. E. (1977). Analysis of self-efficacy theory of behavioral change. Cognitive Therapy and Research, 1(4), 287310. https://doi.org/10.1007/BF01663995

Benny, N. \& Blonder, R. (2016). Factors that promote/inhibit teaching gifted students in a regular class: results from a professional development program for chemistry teachers, Education Research International, Article ID 2742905, 1-11. https://doi.org/10.1155/2016/2742905

Bernal, E. M. (2003). To no longer educate the gifted: programming for gifted students beyond the era of inclusions, Gifted Child Quarterly, 47 (3), 183-191.

https://doi.org/10.1177/001698620304700302

Best, M., Dickinson, C., Hugstad-Vaa Leer, H., Courtney, \& Molly, K. (2017). The impact of implementing core curriculum in an outdoor classroom on primary-aged students' academic achievement, Masters of Arts in Education Action Research Papers. https://sophia.stkate.edu/maed/233/

Bong, M., Cho, C., Ahn, H. S., \& Kim, H. J. (2012). Comparison of self-beliefs for predicting student motivation and achievement. The Journal of Educational Research, 105(5), 336-352. https://doi.org/10.1080/00220671.2011.627401

Borders, C., Woodley, S. \& Moore, E. (2014). Inclusion and giftedness. In J. P. Bakken, F. E. Obiakor \& A. F. Rotatori (Eds.), Gifted education: current perspective and issues. USA: British Library Catalouguing Data. 
Bleicher, R. E., \& Lindgren, J. (2005). Success in science learning and preservice science teaching self-efficacy. Journal of Science Teacher Education, 16, 205- 225. https://doi.org/10.1007/s10972-005-4861-1

Callahan, C. M., Moon, T. R., Oh, S., Azana, A. P. \& Haieley, E. P. (2015). What works in gifted education: documenting the effects of an integrated curricular/instructional model for gifted students, American Educational Research Journal, 52(1), 137-167. https://doi.org/10.3102/0002831214549448

Caldwell, D. W. (2012). Educating gifted students in the regular classroom: efficacy, attitudes, and differentiation of instruction, Electronic Theses and Dissertations. 822. https://digitalcommons.georgiasouthern.edu/etd/822

Campbell, D. T. \& Stanley, J. C. (1963). Experimental and quasi-experimental designs for research on teaching. In N. L. Gage (Ed.), Handbook of research on teaching (pp. 171246). Chicago, IL: Rand McNally. https://www.sfu.ca/ palys/Campbell\&Stanley-1959Exptl\&QuasiExptlDesignsForResearch.pdf

Carrier, M.,Thomsona, M.,Tugurianband, L. B. \& Stevenson, K. T. (2014). Elementary Science Education in Classrooms and Outdoors: Stakeholder views, gender, ethnicity, and testing, International Journal of Science Education 36(13), 1-26. https://doi.org/10.1080/09500693.2014.917342

Ciray Ozkara, F., \& Guven, M. (2018). Identification of requirements of primary school teacher candidates for science education. Journal of Qualitative Research in Education, 6(3), 158-184. https://doi.org/10.14689/issn.2148-2624.1.6c3s8m

Chang, H. P., Chen, C. C., Guo, G. J., Cheng, Y. J., Lin, C. Y., \& Jen, T. H. (2011). The development of a competence scale for learning science: Inquiry and communication. International Journal of Science and Mathematics Education, 9(5), 1213-1233. https://doi.org/10.1007/s10763-010-9256-x.

Chowdhury, M. A. (2016). Gifted education in science and chemistry: Perspectives and insights into teaching, pedagogies, assessments, and psychosocial skills development. Journal for the Education of Gifted Young Scientists, 4(1), 53-66. http://dx.doi.org/10.17478/JEGYS.2018116581

Cohen, L., Manion, L. \& Morrison, K. (2007). Research methods in education ( $6^{\text {th }}$ edition). London: Routledge.

Creswell, J. W , Klassen, A. C., Plano Clark, V. L. and Smith, K. C. (2011). Best Practices for Mixed Methods Research in the Health Sciences, Bethesda (Maryland): National Institutes of Health. http://www2.jabsom.hawaii.edu/native/docs/tsudocs/Best Practices for Mixed Methods Res earch_Aug2011.pdf

Creswell, J. W., \& Plano Clark, V. L. (2014). Designing and conducting mixed methods research (5nd ed.). London: Sage Publications Ltd.

Creswell, J. W., Fetters, M. D., Plano Clark, V. L., and Morales, A. (2009). Mixed methods intervention trials. In S. Andrew \& L. Halcomb (Eds.), Mixed methods research for nursing and the health sciences (pp. 161-180). Oxford, UK: Blackwell. Google Books.

Dellinger, A. B., Bobbett, J. J., Olivier, D. F., \& Ellett, C. D. (2008). Measuring teachers' selfefficacy beliefs: Development and use of the TEBS-Self. Teaching and Teacher Education, 24, 751-766. https://doi.org/10.1016/j.tate.2007.02.010

DeWitt, J. \& Osborne, J. (2007). Supporting teachers on science- focused school trips: Towards an integrated framework of theory and practice. International Journal of Science Education, 29 (6), 685-710. https://doi.org/10.1080/09500690600802254

Ekici, G. (2012). Akademik öz-yeterlik ölçeği: Türkçeye uyarlama, geçerlik ve güvenirlik çalışması [Academic self-efficacy scale: adaptation to Turkish, validity and reliability 
study]. Hacettepe University Journal of Education,43, 174-185. https://toad.halileksi.net/sites/default/files/pdf/akademik-ozyeterlilik-olcegi-toad.pdf

Emir, S. \& Yaman, Y. (2017). Özel yetenekli öğrenciler için eğitim programı nasıl olmalı? [How to design a program in gifted education?] (Ed. S. Emir). Özel yeteneklilerin eğitiminde program tasarımı [Curriculum design in gifted education]. Ankara.

Fisman, L. (2005). The effects of local learning on environmental awareness in children: an emprirical investigation. The Journal of Enviromental Education, 36(3), 39-50. https://doi.org/10.3200/JOEE.36.3.39-50

Jarvis, T. \& Pell, A. (2002). Effect of the challenger experience on elementary children's attitudes to science. Journal of Research in Science Teaching, 39(10), 979-1000. https://doi.org/10.1002/tea.10055

Johnson, S., \& Goree, K. (2005). Teaching gifted students through independent study. In F. Karnes \& S. Beans (Eds.), Methods and materials for teaching the gifted and talented, 379-408. Waco, TX: Prufrock Press.

Harlen, W. (2001). Research in primary science education. Journal of Biological Education, 35(2), 61-65. https://doi.org/10.1080/00219266.2000.9655743

Harshbarger, D. K. (2015). Exploring preservice teachers' perceptions of differentiated science instruction. ETD collection for University of Nebraska - Lincoln. AAI3716433.https://digitalcommons.unl.edu/dissertations/AAI3716433

Hertberg-Davis, H. (2009). Myth 7: Differentiation in the regular classroom is equivalent to gifted programs and is sufficient: Classroom teachers have the time, the skill, and the will to differentiate adequately. Gifted Child Quarterly, 53(4), 251-253. https://doi.org/10.1177/0016986209346927

Heacox, D. (2002). Differentiating instruction in the regular classroom: How to reach and teach all learners, grades. Minneapolis: Free Sipirit Publishing. Google Books.

Hechter, R. (2011). Changes in preservice elementary teachers' personal science teaching efficacy and science teaching outcome expectancies: The influence of context. Journal of Science Teacher Education, 22, 187-202. https://doi.org/10.1007/s10972-010-9199-7

Holbrook, J. \& Rannikmae, M. (2007). The nature of science education for enhancing scientific literacy, International Journal of Science Education, 29(11), 1347-1362. https://doi.org/10.1080/09500690601007549

Kaplan, S. N. (2012). Theory into practice, Gifted Child Today, 35 (4), 295-296. https://doi.org/10.1177/1076217512455484

Karademir, E. and Erten, S. (2013). Determining the factors that affect the objectives of preservice science teachers to perform outdoor science activities. International Journal of Education in Mathematics, Science and Technology, 1(4), 270-293. https://ijemst.net/index.php/ijemst/article/view/17/17

Kutlu Abu, N., Akkanat, Ç. and Gokdere, M. (2017). Teachers' views about the education of gifted students in regular classrooms, Turkish Journal of Giftedness and Education, 7(2), 87-109. http://www.tuzed.org/publications/cilt7/2/tuzed $2017 \quad 7 \quad 2$ abu\&others.pdf

Kinskey, M. (2018) Using action research to improve science teaching self-efficacy, International Journal of Science Education, 40 (15), 1795-1811, https://doi.org/10.1080/09500693.2018.1502898

Knaggs, C., \& Sondergeld, T. (2015). Science as a learner and as a teacher: Measuring science selfefficacy of elementary preservice teachers. School Science and Mathematics, 115(3), 117-128. https://doi.org/10.1111/ssm.12110

Koch, T. (1994). Establishing rigour in qualitative research: The decision trail. Journal of Advanced Nursing, 19, 976-986. http://doi:10.1111/ j.1365-2648.1994.tb01177.x

Launder, B. (2011). Supporting gifted students in the regular education elementary classroom through differentiated instruction, Master thesis, Bowling Green State University, US. 
Lederman, N. G., Lederman, J. S., \& Antink, A. (2013). Nature of science and scientific inquiry as contexts for the learning of science and achievement of scientific literacy. International Journal of Education in Mathematics, Science and Technology, 1(3), 138147. https://files.eric.ed.gov/fulltext/ED543992.pdf

Lincoln, Y.S., \& Guba, E.G. (1985). Naturalistic inquiry. Newbury Park, CA: SAGE

Martín-Gutiérrez, J., Mora, C. E., Añorbe-Díaz, B., \& González-Marrero, A. (2017). Virtual technologies trends in education. EURASIA Journal of Mathematics Science and Technology Education, 13(2), 469-486. https://doi.org/10.12973/eurasia.2017.00626a

Menon, D., \& Sadler, T. (2016). Preservice elementary teachers' science self-efficacy beliefs and science content knowledge. Journal of Science Teacher Education, 27, 649-673. https://doi.org/10.1007/s10972-016-9479-y

Morentin, M. \& Guisasola, J. (2009). Patterns of teachers'thinking on school visits to a science museum. In M.F. Taşar \& G. Çakmakçı (Eds.), Contemporary science education research: international perspectives (pp. 409-411). Ankara, Turkey: Pegem Akademi

Morrell, P. D., \& Carroll, J.B. (2003). An extended examination of preservice elementary teachers' science teaching self-efficacy, School Science and Mathematics, 103, 246-251. https://doi.org/10.1111/j.1949-8594.2003.tb18205.x

National Science Teachers Association (NSTA). 2014. Early Childhood Science Education. Arlington, VA: NSTA. http://static.nsta.org/pdfs/PositionStatement_EarlyChildhood.pdf

Nielsen, M. E. \& Knudson, D. M. (1992). Outdoor Experiences for the Gifted. Historical Documents of the Purdue Cooperative Extension Service. Paper 870. https://docs.lib.purdue.edu/agext/870

Olszewski-Kubilius, P. and Thomson, D. (2015). Talent development as a framework for gifted education, Gifted Child Today, 38(1), 49-59. https://doi.org/10.1177/1076217514556531

Oguz, A. (2012). Sınıf öğretmeni adaylarının akademik öz yeterlik inançları çalışması [Academic self-efficacy beliefs of prospective primary school teachers]. Anadolu Journal of Educational Sciences International, 2(2), 15-28. http://ajesi.dergi.anadolu.edu.tr/yonetim/icerik/makaleler/14-published.pdf

Ozkan, O., Tekkaya, C. \& Cakiroglu, J. (2002), Fen bilgisi aday öğretmenlerin fen kavramlarını anlama düzeyleri, fen ögretimine yönelik tutum ve öz yeterlik inançları [Science teachers' understanding of science concepts, attitudes towards science teaching and self-efficacy beliefs]. V. Fen ve Matematik Kongresi, Ankara. http://infobank.fedu.metu.edu.tr/ufbmek5/netscape/b_kitabi/PDF/OgretmenYetistirme/Bildiri/t300.pdf

Pajares F. and Schunk D., (2001), The development of academic self-efficacy, in Wigfield A. and Eccles J. (ed.), Development of achievement motivation, San Diego: Academic Press.

Patton, M. Q., (2014), Qualitative Research \& Evaluation Methods Integrating Theory and Practice (Fourth Edition), Sage Publications, Thousand Oaks, CA.

Powers, E. A. (2008). The use of independent study as a viable differentiation technique for gifted learners in the regular classroom. Gifted Child Today, 31(3), 57-65.

Prior, S. (2011). Student voice: What do students who are intellectually gifted say they experience and need in the inclusive classroom? Gifted and Talented International, 26(1-2), 121-130. https://doi.org/10.1080/15332276.2011.11673596

Randler, C., Baumgärtner, S., Eisele, H. \& Kienzle, W. (2007). Learning at workstations in the zoo: a controlled evaluation of cognitive and affective outcomes. Visitor Studies, 10(2), 205-216. https://doi.org/10.1080/10645570701585343

Rapley, T. (2007). The Sage qualitative research kit. Doing conversation, discourse and document analysis. Sage Publications Ltd. https://doi.org/10.4135/9781849208901 
Renzulli, J. S., and Reis, S. M. (2009). A technology-based application of the schoolwide enrichment Model and high-end learning theory. In L. Shavinina (Ed.), International handbook on giftedness (pp. 1203-1223). New York, NY: Springer.

Renzulli, J. S. (2012). Reexamining the role of gifted education and talent development for the $21^{\text {st }}$ century: A four-part theoretical approach, Gifted Child Quarterly, 56(3) 150-159. https://doi.org/10.1177/0016986212444901

Renzulli, J. S. (2005). Applying gifted education pedagogy to total talent development for all students, Theory into Practices, 44(2), 80-89. https://doi.org/10.1207/s15430421 tip4402_2

Renzulli, J. S. \& Reis, S. (2007). A techonology based program that matches enrichment resources with student strenghths, International Journal of Emerging Techonologies in Learning (iJET), 2(3), 1-12. https://online-journals.org/index.php/i-jet/article/view/126

Reaume, R. (2011). Pre-service teacher perceptions of and experiences with implementation of inquiry based science teaching. Electronic Theses and Dissertations. http://scholar.uwindsor.ca/etd/109.

Robinson, A., Shore, B. M., \& Enersen, D. L. (2006). Best practices in gifted education: An evidence-based guide. Naperville, IL: Sourcebooks.

Rogers, K. B. (2002). Grouping the gifted and talented: Questions and answers. Roeper Review 16(1), 8-12. https://doi.org/10.1080/02783199309553526

Rowley, J. L. (2002). Teacher effectiveness in the education of gifted students: A comparison of trained, trainee and untrained teachers of gifted and talented students, The University of New South Wales.

Reis, S., Westberg, K., Kulkiowich, J., Caillard, F., Hébert, T., Plucker, J., Purcell, J., Rogers, J., \& Smist, J. (1993). Why not let high ability students start school in January: The curriculum compacting study (Research Monograph 93106). Storrs: University of Connecticut, National Research Center on the Gifted and Talented. https://nrcgt.uconn.edu/wp-content/uploads/sites/953/2015/09/rm93106.pdf

Riggs, I. M., \& Enochs, L. G. (1990). Toward the development of an elementary teacher's science teaching efficacy belief instrument. Science Education, 74(6), 625637. https://doi.org/10.1002/sce.3730740605

Robinson, A., Shore, B. M. \& Enersen, D. (2007), Üstün zekalılar eğitiminde en iyi uygulamalar [Best practices in gifted education]. Nobel Press (Trans. Edit. Oğurlu \& Kaya), Ankara.

Rogers, K. B. (2002). Reforming gifted education. Scottsdale, AZ: Great Potential Press. Eric, ED459570

Sapon-Shevin, M., Ayres, B.J., \& Duncan, J. (1994). Cooperative learning and inclusion. In J.S. Thousand, R.A. Villa, \& A.I. Nevin (Eds.), Creativity and collaborative learning: A practical guide to empowering students and teachers (pp. 45-58). Baltimore: Paul H. Brookes Publishing Co.

Savasçi-Açikalin, F. (2013). A study of pre-service teachers' science teaching efficacy beliefs during the elementary science laboratory course, Procedia - Social and Behavioral Sciences 141, $221-226$, https://doi.org/10.1016/j.sbspro.2014.05.038

Schunk, D. H. (1991). Self-efficacy and academic motivation. Educational Psychologist, 26, 207-231. https://doi.org/10.1080/00461520.1991.9653133

Stepanek, J. (1999). The inclusive classroom. Meeting the needs of gifted students: Differentiating mathematics and science instruction. Portland, OR: Northwest Regional Educational Lab. https://files.eric.ed.gov/fulltext/ED444306.pdf

Stephens, K. R. \& Karnes, F. A. (2016). Curriculum design in gifted education. Waco, Texas: Prufrock Press. 
Smith, M. M. C. (2006). Principles of inclusion. İmplications for able learners. In M.M.C. Smith (Ed.), Including the gifted and talented. Making inclusion work for more gifted and able learners. New York, Oxon:Routledge.

Silverman, L. K. (1994). The moral sensitivity of gifted children and the evolution of society. Roeper review, 17(2), 110-116. https://doi.org/10.1080/02783199409553636Smith, M. M. C. (2006). Including the gifted and talented. Making inclusion work for more gifted and able learners. New York, Oxon:Routledge.

Stepanek, J. (1999). The inclusive classroom. Meeting the needs of gifted students: Differentiating mathematics and science instruction. Portland, OR: Northwest Regional Educational Lab.

Slater, T.F., Ryan. J.M, \& Samson, S.L (1997). The impact and dynamics of portfolio assessment and traditional assessment in college physics. Journal of Research in Science Teaching, 3, 255-271. https://doi.org/10.1002/(SICI)10982736(199703)34:3<255::AID-TEA4>3.0.CO;2-R

Swiatek, M. A. \& Lupkowski-Shoplik, A. (2003). Elementary and middle school student participation in gifted programs: are gifted students underserved?, Gifted Child Quarterly, 47(2), 118-130. https://doi.org/10.1177/001698620304700203

Senler, B. (2014). Turkish adaptation of the competence scale for learning science: Validity and reliability study. Journal of Theory and Practice in Education, 10(2), 393407.https://toad.halileksi.net/sites/default/files/pdf/fen-ogrenme-becerisi-olcegi-toad.pdf

Seidman, I. (2012) Interviewing as qualitative research: A guide for researchers in education and the social sciences. Teachers college press.

Sökmen, Y. (2019). The role of self-efficacy in the relationship between the learning environment and student engagement, Educational Studies, 1-19. https://doi.org/10.1080/03055698.2019.1665986

Schunk, D. H. (1985). Self-efficacy and classroom learning. Psychology in the Schools, 22 (2), 208-223. https://doi.org/10.1002/1520-6807(198504)22:2<208::AIDPITS2310220215>3.0.CO;2-7

Stephens, K. R. \& Karnes, F. A. (2016). Curriculum design in gifted education. Waco, Texas: Prufrock Press.

Taber, K. S. (2011). Ustun yetenekliler için fen eğitimi [Science education for gifted learners], (Trans. Ed. M. Gokdere), Ankara.

Tomlinson, C. A. (2003). Deciding to teach them all. Educational Leadership, 61(2), 6-11. http://www.ascd.org/publications/educational-leadership/oct03/vol61/num02/Deciding-toTeach-Them-All.aspx

Tomlinson, C. A. (2001). Differentiation of instruction in the elementary grades. Champaign, IL: ERIC Clearinghouse on Elementary and Early Childhood Education.

Tomlinson, C. A, Brighton, C., Hertberg, H., Callahan, C. M., Moon, T. R., Brimijoin, K., et al. (2003). Differentiating instruction in response to student readiness, interest, and learning profile in academically diverse classrooms: A review of literature. Journal for the Education of the Gifted, 27(2/3), 119-145. https://files.eric.ed.gov/fulltext/EJ787917.pdf

Tomlinson, C. A. (2004). Sharing responsibility for differentiating instruction. Roeper Review, 26(4), 188-200. https://doi.org/10.1080/02783190409554268

Tsai, J. T. (2006). The identification of the components for an outdoor education curriculum in Taiwan. (The School of Health, Physical Education and Recreation Indiana University. Tschannen-Moran, M., \& Hoy, A. W. (2001). Teacher efficacy: Capturing an elusive construct. Teaching and Teacher Education, 17(7), 783-805. https://doi.org/10.1016/S0742$\underline{051 X(01) 00036-1}$ 
Trauth-Nare, A. (2015). Influence of an intensive, field-based life science course on preservice teachers' self-efficacy for environmental science teaching. Journal of Science Teacher Education, 26, 497-519. https://doi.org/10.1007/s10972-015-9434-3

Troxclair, D. (2000). Differentiating instruction for gifted students in regular education social studies classes. Roeper Review, 22, 195-198. https://doi.org/10.1080/02783190009554033

Tschannen-Moran, M., \& Hoy, A. W. (2001). Teacher efficacy: Capturing an elusive construct. Teaching and Teacher Education, 17(7), 783-805. https://doi.org/10.1016/S0742$\underline{051 X(01) 00036-1 .}$.

Uitto, A., Juuti, K., Lavonen, J. \& Meisalo, V. (2006). Students' interest in biology and their out-of-school experiences. Journal of Biological Eucation, 40(3), 124-129. https://doi.org/10.1080/00219266.2006.9656029.

Ustun, U., \& Eryilmaz, A. (2014). A research methodology to conduct effective research syntheses:__ Meta-analysis, Education and Science, 39(174), 1-32. http://dx.doi.org/10.15390/EB.2014.3379

Waite, S. (2009). Teaching and learning outside the classroom: personal values, alternative pedagogies and standards, Education 3-13, 39(1), 65-82. https://doi.org/10.1080/03004270903206141

Westberg, K., Archambault, F., Dobyns, S. \& Slavin, T. (1993). An observational study of instructional and curricular practices used with gifted and talented students in regular classrooms. Storrs, CT: National Research Center on the Gifted and Talented. https://files.eric.ed.gov/fulltext/ED379846.pdf

VanTassel-Baska, J., \& Brown, E. F. (2007). Toward best practice: An analysis of the efficacy of curriculum models in gifted education. Gifted Child Quarterly, 51(4), 342358. https://doi.org/10.1177/0016986207306323

VanTassel-Baska, J. (2000). Theory and research on curriculum development for the gifted. In K. A. Heller, F. J. Mönks, R. J. Sternberg and R. F. Subotnik (Eds), International handbook of giftedness and talent (2nd ed. pp 345-365). Oxford, UK: Elsevier Science Ltd.

VanTassel-Baska, J., \& Wood, S. (2010). The integrated curriculum model (ICM). Learning and Individual Differences, 20(4), 345-357. https://doi.org/10.1016/j.lindif.2009.12.006.

VanTassel-Baska, J. \& Stambaugh, T. (2005) Challenges and possibilities for serving gifted learners in the regular classroom, Theory Into Practice, 44(3), 211-217. https://doi.org/10.1207/s15430421tip4403 5

Vaivre-Douret, L. (2011). Developmental and cognitive characteristics of high-level potentialities children, International Journal of Pediatrics, 1-14. https://doi.org/10.1155/2011/420297

Zajacova, A., Lynch, S. M., \& Espenshadet, T. J. (2005). Self-efficacy, stres and academic success in college. Research in Higher Education, 46(6), 677-698. https://doi.org/10.1007/s11162-004-4139-z

Zoldosova, K. \& Prokop, P. (2006). Education in the field influences children's ideas and interest toward science. Journal of Science Education and Technology, 15(3), 304-313. https://doi.org/10.1007/s10956-006-9017-3 